\title{
Molecular variants of the ATM gene in Hodgkin's disease in children
}

\author{
E Liberzon', S Avigad ${ }^{*, 1,2}$, I Yaniv 1,2, B Stark², G Avrahami' ${ }^{2}$, Y Goshen ${ }^{2}$ and R Zaizov ${ }^{1,2}$ \\ 'Molecular Oncology, Felsenstein Medical Research Center, Petah Tikva, Sackler Faculty of Medicine, Tel Aviv University, Tel Aviv, Israel; ${ }^{2}$ Pediatric \\ Hematology Oncology, Schneider Children's Medical Center of Israel, Petah Tikva, Sackler Faculty of Medicine, Tel Aviv University, Tel Aviv, Israel
}

Ataxia telangiectasia is an autosomal recessive disease with a striking predisposition of lymphoid malignancies. ATM mutations have been reported in adult sporadic lymphoma and leukaemia. The aim of this study was to investigate the possible involvement of the ATM gene in the carcinogenesis of Hodgkin disease in children. Tumours were obtained from 23 patients and were subjected to mutation screening and loss of heterozygosity analysis. Eight base substitutions were identified in seven patients. Of them, Y54Y, a silent change, was observed in two patients and a known polymorphism, DI853N, in three patients. Of the other two patients, one harboured a combined genotype P604S/FI 463C, identified previously in two patients with Hodgkin lymphoma, and the other a novel missense mutation, V595A. The alterations were present in the germ line, and both had a more aggressive disease. In all, I00 matched normal ethnic controls were screened for these mutations and P604S/FI463C was identified in one healthy control. Loss of heterozygosity was identified in four patients and in three of them it was located centromeric to the ATM gene, and, in one, it spanned a large region, indicating the involvement of other tumour-suppressor genes in this disease. Missense variants of the ATM gene are a rare event in childhood Hodgkin disease.

British Journal of Cancer (2004) 90, 522 -525. doi:I0.1038/sj.bjc.660I522 www.bjcancer.com

(c) 2004 Cancer Research UK

Keywords: ATM; Hodgkin lymphoma; mutations

Ataxia telangiectasia (A-T) is an autosomal recessive disorder characterised by telangiectasia, progressive ataxia, pulmonary infections, radiosensitivity and a combined immunodeficiency (Shiloh, 1995). Ataxia telangiectasia patients show an increased genomic instability, which results in translocations and inversions, leading to 100-fold cancer excess, particularly lymphoid malignancies (Morrell et al, 1986; Taylor et al, 1996). The most common lymphoid neoplasms are non-Hodgkin lymphomas, followed by acute lymphoblastic leukaemia and Hodgkin disease (5-10\%) (Hecht and Hecht, 1990).

The ATM gene is responsible for A-T, located on chromosome 11q22-23, and encodes for serine-threonine kinase belonging to the phosphatidylinositol 3-kinase (PI3-K) family, and plays a central role in signalling pathways activated by DNA damage (Savitsky et al, 1995a,b). Different studies identified a number of ATM targets including c-abl, TP53, CHK-2, NBS1 and BRCA1 (Shiloh, 2003).

Ataxia telangiectasia heterozygotes have been suggested to have a reduced life expectancy owing to a higher frequency of ischaemic heart disease (Su and Swift, 2000) and an increased risk for cancer, particularly for carcinoma of the breast (Swift et al, 1991; Broeks et al, 2000; Olsen et al, 2001). Several studies have indicated that ATM may also be involved in the development of some subtypes of sporadic lymphoma and leukaemia. Missense and truncation mutations in the ATM gene have been demonstrated in adult leukaemias: T-cell prolymphocytic leukaemia (T-PLL) (Stilgen-

*Correspondence: S Avigad, Pediatric Hematology Oncology, Schneider Children's Medical Center of Israel, I 4 Kaplan Street, Petah Tikva 49202. Israel; E-mail: savigad@post.tau.ac.il

Received 29 May 2003; revised 7 October 2003; accepted 24 October 2003 bauer et al, 1997; Vorechovsky et al, 1997; Stoppa-Lyonnet et al, 1998; Yuille et al, 1998), and B-cell chronic lymphocytic leukaemia (B-CLL) (Bullrich et al, 1999; Schaffner et al, 1999; Stankovic et al, 1999; 2002). In adult lymphomas, Vorechovsky et al (1997) first demonstrated two missense variants in 32 non-Hodgkin lymphomas. In addition, missense and loss-of-function mutations were identified in mantle cell lymphoma (MCL), mainly associated with 11q22-23 loss of heterozygosity (LOH) (Stilgenbauer et al, 1999; Schaffner et al, 2000; Camacho et al, 2002). ATM mutations have been reported in diffuse large B-cell lymphoma (DLBCL) and follicular lymphoma (FL) (Gronbaek et al, 2002). Recently, Offit et al (2002) reported that ATM variants are rare in Hodgkin lymphoma and in radiation-induced breast cancer after treatment for Hodgkin disease.

The aim of the study was to investigate the possible involvement of ATM gene in the pathogenesis of Hodgkin lymphoma in children.

\section{MATERIALS AND METHODS}

A total of 23 children with Hodgkin's disease participated in the study that was approved by the ethics committee of the hospital. Tumours were obtained from patients at diagnosis treated at the Center for Pediatric Hematology Oncology, Schneider Children's Medical Center of Israel, between 1988 and 2001, and were snapfrozen in liquid nitrogen. The cohort consisted of 13 male and 10 female patients, ranging in age from 4.5 to 17.5 years (median 13 years). The tumours were classified according to the criteria established by Lukes and Butler (1966). The tumours belonged to the histological subtypes as follows: 19 nodullar sclerosis (NS) and four mixed cellularity (MC). 
Total RNA was extracted from the tumours using the TRIReagent (Molecular Research Center, Cincinnati, OH, USA), according to the manufacturer's instructions. Reverse transcription (RT) was performed using random hexamers and ready-to-Go RT - PCR beads (Amersham Biosciences, Piscataway, NJ, USA) for nine overlapping fragments of the ATM gene, according to instructions. Long SSCP analysis was performed on the RT-PCR products, as previously described (Kukita et al, 1997). A suspected sample was subjected to direct sequencing using the cycling sequencing system (Applied Biosystems, Foster City, CA, USA) and run on Perkin-Elmer ABI-377 automatic sequencer.

High molecular DNA was extracted from normal and tumour tissues using standard procedures. An identified mutation was verified on the tumour DNA and then on the normal DNA (PBL) for the identification of a germ-line mutation.

Each specific missense mutation was screened in 100 matched normal ethnic group: Ashkenazim or Arabs or non-Ashkenazim, a total of 300 normal controls. The mutations were screened using SSCP analysis for each of the three exons $-13,31$ and 39. Restriction analysis using $S s p \mathrm{I}$ and $M n l \mathrm{I}$ was used for the mutations in exons 5 and 14, respectively.

Loss of heterozygosity analysis was performed on 15 paired tumour and blood DNA samples using four microsatellite markers. Two markers were located within the 11q22-q23 locus (D11S1778, D11S1817) and two in the ATM gene (NS22 and D11S2179).

\section{RESULTS}

Mutation analysis revealed eight alterations in seven out of 23 patients (30\%) (Table 1). All of the alterations were base substitutions, and in all cases the wild-type allele was preserved.

Normal tissue was available in all seven patients and their normal DNA was screened for identified alterations. In all, the alterations were present in the germ-line. The frequency of ATM variants was analysed in samples of matched ethnic origin (Table 1). Five patients were found to have two polymorphic changes: Y54Y in exon 5 and D1853N in exon 39. Two patients of Arab origin harboured the silent change Y54Y, which was observed with similar frequency in the Hodgkin lymphoma patients and matched ethnic controls, 0.04 and 0.03 , respectively. D1853N was observed in three patients of non-Ashkenazim origin, at an allele frequency of 0.07 in our Hodgkin lymphoma patients and at a frequency of 0.12 in the matched ethnic normal population.

The other alterations were P604S/F1463C in exons 14 and 31, respectively. The P604S/F1463C combined genotype was identified in one Hodgkin lymphoma of a mixed Ashkenazim/Iraqi origin and in one of the control cases. The frequency of each allele separately in the normal population was 0.015 and 0.02 for P604S and F1463C, respectively. The novel mutation V595A was observed in a Bedouin patient and in none out of 100 ethnic matched controls.

Loss of heterozygosity analysis was performed on 15 paired tumour and normal samples. In all, 12 patients were informative in at least two markers and four (33\%) exhibited LOH (Table 2). In

Table I ATM alterations in Hodgkin's lymphoma tumours and matched ethnic controls

\begin{tabular}{lcccc}
\hline Exon & $\begin{array}{c}\text { Nucleotide } \\
\text { change }\end{array}$ & $\begin{array}{c}\text { Amino-acid } \\
\text { change } \\
\text { (codon) }\end{array}$ & $\begin{array}{c}\text { Frequency } \\
\text { Hodgkin's } \\
\text { lymphoma }\end{array}$ & $\begin{array}{c}\text { Frequency } \\
\text { controls }\end{array}$ \\
\hline 5 & $162 T \rightarrow C$ & $Y 54 Y$ & 0.04 & 0.03 \\
13 & $1784 T \rightarrow C$ & $V 595 \mathrm{~A}$ & 0.02 & 0 \\
$14,3 \mid$ & $|8| 0 C \rightarrow T / 4388 \mathrm{~T} \rightarrow \mathrm{G}$ & $\mathrm{P} 604 \mathrm{~S} / \mathrm{FI} 463 \mathrm{C}$ & 0.02 & 0.003 \\
39 & $5557 \mathrm{G} \rightarrow \mathrm{A}$ & $\mathrm{D} / 853 \mathrm{~N}$ & 0.07 & 0.12 \\
\hline
\end{tabular}

${ }^{\mathrm{a} A l l e l i c ~ c o u n t s . ~}$
Table $2 \mathrm{LOH}$ analysis of Hodgkin's lymphoma tumors

\begin{tabular}{|c|c|c|c|c|c|}
\hline \multirow{2}{*}{$\begin{array}{l}\text { Patient } \\
\text { no. }\end{array}$} & \multirow{2}{*}{$\begin{array}{c}\text { CEN } \\
\text { DIISI8I7 }\end{array}$} & \multicolumn{3}{|c|}{ ATM gene } & \multirow{2}{*}{$\begin{array}{c}\text { TEL } \\
\text { DIISI778 }\end{array}$} \\
\hline & & NS22 & DIIS2I79 & Genotype & \\
\hline I & + & + & + & DI853N土 & + \\
\hline 2 & - & + & + & P604S/FI463C \pm & + \\
\hline 3 & + & + & + & & + \\
\hline 4 & $\mathrm{LOH}$ & INS & - & Y54Y \pm & - \\
\hline 7 & - & - & - & DI853N \pm & + \\
\hline 8 & - & + & + & & + \\
\hline 9 & + & + & - & DI853N土 & - \\
\hline 10 & + & & + & & - \\
\hline 11 & - & \pm & + & & + \\
\hline 12 & - & + & + & Y54Y \pm & - \\
\hline 13 & $\mathrm{LOH}$ & INS & - & & + \\
\hline 14 & + & - & - & & - \\
\hline 15 & $\mathrm{LOH}$ & + & + & & - \\
\hline 17 & $\mathrm{LOH}$ & $\mathrm{LOH}$ & - & & $\mathrm{LOH}$ \\
\hline 18 & - & - & + & & - \\
\hline
\end{tabular}

CEN = centromeric; TEL = telomeric; - : not informative; + : informative; $\mathrm{LOH}=$ loss of heterozygosity; INS = microsatellite instability. \pm heterozygote.

three patients, the region of $\mathrm{LOH}$ was located centromeric to the ATM gene and, in one, the LOH spanned a large region, including the markers centromeric and telomeric to the ATM gene. In addition, two patients showed genomic instability in the NS22 marker, which is located in the ATM gene.

Three out of 23 patients were studied, relapsed, and in two of them ATM missense alterations were identified. The patient harbouring the combined genotype P604S/F1463C relapsed within 12 months after diagnosis and expired 7 months later. The other patient, carrying the V595A alteration, relapsed twice, after 28 months and subsequently after additional 10 months, following autologous bone marrow transplantation.

\section{DISCUSSION}

In this study, ATM missense variants were detected in two out of 23 (9\%) childhood Hodgkin tumours. All alterations were present in the germ-line. These two patients had a more aggressive clinical course of the disease.

The P604S/F1463C genotype was reported previously in two Hodgkin's disease patients of Ashkenazi origin (Offit et al, 2002). It is of note that our patient was of a mixed Ashkenazi/Iraqi origin. Unfortunately, we were unable to determine the origin of the mutation, as his parents were not available for analysis. The novel mutation V595A was observed in a Bedouin patient who inherited it from his mother, and was not identified in 100 matched normal ethnic population.

In addition, we detected two polymorphic changes that have been described in previous studies. Y54Y silent change was described recently in an A-T patient who harboured two truncation mutations (Buzin et al, 2003). D1853N is a wellestablished known polymorphism that was observed at a similar frequency in cancer patients and in controls reported in other studies (Thorstenson et al, 2001; Offit et al, 2002).

Four out of 12 informative patients exhibited $\mathrm{LOH}$ centromeric to ATM locus, and only in one patient $\mathrm{LOH}$ encompassed the whole ATM region. Thus, LOH of the ATM gene is rarely involved in childhood Hodgkin disease. In molecular and cytogenetic studies of Hodgkin disease, loss of $11 \mathrm{q}$ was found to be a rare event (Tilly et al, 1991; Dohner et al, 1992; Ohsima et al, 1999). In a report utilising one marker telomeric to the ATM locus, three out of seven Hodgkin patients exhibited LOH in the this region (Hasse et al, 1999). All these observations may suggest that other tumour- 
suppressor genes that reside in $11 \mathrm{q}$ region may be involved in childhood Hodgkin's disease.

No protein truncation mutations were identified in our childhood Hodgkin lymphoma tumours, similar to the absence of truncation mutations reported in another study (Offit et al, 2002), which included both adults and children. Moreover, no truncating germ-line ATM mutations were detected in 52 survivors of Hodgkin's disease, adults and children, who developed secondary neoplasms (Nichols et al, 1999).

In studies of ATM gene involvement in adult sporadic lymphoid malignancies, missense and truncation mutations, both somatic and germ-line origin, were identified. In T-PLL, missense mutations clustered to the PI3-K region (Vorechovsky et al, 1997), while in B-CLL (Stankovic et al, 1999), MCL (Camacho et al, 2002) and DLBCL (Gronbaek et al, 2002) missense mutations spread across the whole gene. Missense variants identified in the present study were located outside the PI3-K region, similar to results in the study by Offit et al (2002). The only alteration in a known domain is the $\mathrm{F} 1463 \mathrm{C}$ variant that resides in the FAT region. In addition, the majority of cases of adult lymphoid malignancies such as MCL and B-CLL show biallelic inactivation of the ATM gene. It is different in children with ALL, in whom single missense mutations with no $\mathrm{LOH}$ involvement were reported (Pause et al, 2003). In our study of childhood T-cell ALL, truncation and missense mutations were detected, also without $\mathrm{LOH}$ involvement, and we could not identify any genetic alteration in T-cell non-Hodgkin's lymphoma (in press). This could suggest a dominant-negative mechanism, as was demonstrated by Scott et al (2002); some missense mutations

\section{REFERENCES}

Broeks A, Urbanus JHM, Floore AN, Dahler EC, Klijn JGM, Rutgers EJTh, Devilee P, Russell NS, van Leeuwen FE, van't Veer LJ (2000) ATMheterozygous germline mutations contribute to breast cancer-susceptibility. Am J Hum Genet 66: 494-500

Bullrich F, Rasio D, Kitada S, Starostik P, Kipps T, Keating M, Albitar M, Reed JC, Croce CM (1999) ATM mutations in B-cell chronic lymphocytic leukemia. Cancer Res 59: 24-27

Buzin CH, Gatti RA, Nguyen VQ, Wen CY, Mitui M, Sanal O, Chen JS, Nozari G, Mengos A, Li X, Fujimura F, Sommer SS (2003) Comprehensive scanning of the ATM gene with DOVAM-S. Hum Mutat 21: $123-131$

Camacho E, Hernandez L, Hernandez S, Tort F, Bellosillo B, Bea S, Bosch F, Montserrat E, Cardesa A, Fernandez PL, Campo E (2002) ATM gene inactivation in mantle cell lymphoma mainly occurs by truncating mutations and missense mutations involving the phosphatidylinositol-3 kinase domain and is associated with increasing numbers of chromosomal imbalances. Blood 99: 238-244

Dohner H, Bloomfield CD, Frizzera G, Frestedt J, Arthur DC (1992) Recurring chromosome abnormalities in Hodgkin disease. Genes Chromosom Cancer 5: 392-398

Gronbaek K, Worm J, Ralfkiaer E, Ahrenkiel V, Hokland P, Guldberg P (2002) ATM mutations are associared with inactivation of the ARF-TP53 tumor suppressor pathway in diffuse large B-cell lymphoma. Blood 100: $1430-1437$

Hasse U, Tigquely M, Leibundgut DE, Cajot J-F, Garvin AM, Tobler A, Borisch B, Fey MF (1999) Clonal loss of heterozygosity in microdissected Hodgkin and Reed-Sternberg cells. J Natl Cancer Inst 91: 1581-1583

Hecht F, Hecht BK (1990) Cancer in ataxia-telangiectasia patients. Cancer Genet Gytogenet 46: 9-19

Kukita Y, Tahira T, Sommer SS, Hayashi K (1997) SSCP analysis of long DNA fragments in low pH gel. Hum Mutat 10: 400-407

Lukes RJ, Butler JJ (1966) The pathology and nomenclature of Hodgkin's disease. Cancer Res 26: $1063-1081$

Morrell D, Cromartie E, Swift M (1986) Mortality and cancer incidence in 263 patients with ataxia telangiectasia. J Natl Cancer Inst 77: 89-92

Nichols KE, Levitz S, Shannon KE, Wahrer DC, Bell DW, Chang G, Hegde S, Neuberg D, Shafman T, Tarbell NJ, Mauch P, Ishioka C, Haber DA, Diller that reside outside the PI3-K region have an effect on ATM downstream targets by a dominant-negative mechanism. In a more recent study by Oguchi et al (2003), the dominant-negative effect of a missense mutation located in the PI3-K domain was demonstrated in a childhood acute leukaemia patient with MLL rearrangement.

Our results indicate that missense variants of the ATM gene occur in Hodgkin's disease in children (9\%), but at a low frequency, and thus do not play a major role in the oncogenesis of the disease in our childhood population in Israel. On the other hand, observation of LOH outside the ATM locus may indicate the involvement of other tumour-suppressor genes in this disease. The presence of missense variants was associated with a more aggressive disease, and further investigation of these substitutions should clarify whether they have any functional effect on the oncogenesis of Hodgkin lymphoma.

\section{ACKNOWLEDGEMENTS}

This research was funded in part by the Israel Cancer Association through a donation from $\mathrm{Mr}$ and Mrs Peter Brown, Florida, in memory of Eric Brown, and by The Josefina Maus and Gabriela Cesarman Maus Chair for Pediatric Hematology Oncology (RZ) Human DNA samples were obtained from The National Laboratory for the Genetics of Israeli Populations at Tel-Aviv University, Israel. This work was performed in partial fulfillment of the requirements for the PhD degree of Ella Liberzon, Sackler School of Medicine, Tel Aviv University, Israel.

L (1999) Heterozygous germline ATM mutations do not contribute to radiation-associated malignancies after Hodgkin's disease. J Clin Onco 17: $1259-1266$

Offit K, Gilad S, Paglin S, Kolachana P, Roisman LC, Nafa K, Yeugelewitz V, Gonzales M, Robson M, McDermott D, Pierce HH, Kauff ND, Einat P, Jhanwar S, Satagopan JM, Oddoux C, Ellis N, Skaliter R, Yahalom J (2002) Rare variants of ATM and risk for Hodgkin disease and radiation induced breast cancers. Clin Cancer Res 8: $3813-3819$

Oguchi K, Takagi M, Tsuchida R, Taya Y, Ito E, Isoyama K, Ishii E, Zannini L, Della D, Mizutani S (2003) Missense mutation and defective function of ATM in a childhood acute patient with MLL gene rearrangement. Blood 101: $3622-3627$

Ohsima K, Ishigiro M, Ohgami A, Sugihara M, Haraoka S, Suzumiya J, Kikuchi M (1999) Genetic analysis of sorted Hodgkin and ReedSternberg cells using comparative genomic hybridization. Int J Cancer 82: $250-255$

Olsen JH, Hahnemann JM, Borrensen-Dale AL, Brondum-Nielsen $\mathrm{K}$, Hammarstrom L, Kleinerman $\mathrm{R}$, Kaariainen $\mathrm{H}$, Lonnqvist $\mathrm{T}$, Sankila R, Seersholom N, Tretli S, Yuen J, Boice Jr JD, Tucker M (2001) Cancer in patients with ataxia-telangiectasia and in their relatives in the Nordic countries. J Natl Cancer Inst 93: $121-127$

Pause FG, Wacker P, Maillet P, Betts D, Sappino A-P (2003) ATM gene alterations in childhood acute lymphoblastic leukemias. Hum Mut 21: 554

Savitsky K, Bar-Shira A, Gilad S, Rotman G, Ziv Y, Vanagaite L, Tagle DA, Smith S, Uziel T, Sfez S, Ashkenazi M, Pecker I, Frydman M, Harnik R, Sankhavaram R, Patanjali SR, Simmons A, Clines GA, Sartiel A, Gatti RA, Chessa L, Sanal O, Lavin MF, Jaspers NGJ, Taylor AMR, Arlett CF, Miki T, Weissman SM, Lovett M, Collins FS, Shiloh Y (1995a) A single ataxia telangiectasia gene with a product similar to PI-3 kinase. Science 268: $1749-1753$

Savitsky K, Sfez S, Tagle DA, Ziv Y, Sartiel A, Collins FS, Shiloh Y, Rotman $\mathrm{G}$ (1995b) The complete sequence of the coding region of the ATM gene reveals similarity to cell cycle regulators in different species. $\mathrm{Hum} \mathrm{Mol}$ Genet 4: $2025-2032$ 
Schaffner C, Idler I, Stilgenbauer S, Dohner H, Lichter P (2000) Mantle cell lymphoma is characterized by inactivation of the ATM gene. Proc Natl Acad Sci USA 97: 2773-2778

Schaffner C, Stilgenbauer S, Rappold GA, Dohner H, Lichter P (1999) Somatic ATM mutations indicate a pathogenic role of ATM in B-cell chronic lymphocytic leukemia. Blood 94: 748-753

Scott SP, Bendix R, Chen P, Clark R, Dork T, Lavin MF (2002) Missense mutations but not allelic variants alter the function of ATM by dominant interference in patients with breast cancer. Proc Natl Acad Sci USA 99: $925-930$

Shiloh Y (1995) Ataxia-telangiectasia. Close to unraveling the mystery. Eur J Hum Genet 3: 116-138

Shiloh Y (2003) ATM and related protein kinases: safeguarding genome integrity. Nat Rev Cancer 3: 155-168

Stankovic T, Stewart GS, Fegan C, Biggs P, Last J, Byrd PJ, Keenan RD, Moss PA, Taylor AM (2002) Ataxia telangiectasia mutated-deficient Bcell chronic lymphocytic leukemia occurs in pregerminal center cells and results in defective damage response and unrepaired chromosome damage. Blood 99: 300-309

Stankovic T, Weber P, Stewart G, Bedenham T, Murray J, Byrd PJ, Moss PAH, Taylor AMR (1999) Inactivation of ataxia telangiectasia mutated gene in B-cell chronic lymphocytic leukemia. Lancet 353: $26-29$

Stilgenbauer S, Schaffner C, Litterst A, Liebisch P, Gilad S, Bar-Shira A, James MR, Lichter P, Dohner H (1997) Biallelic mutations in the ATM gene in T-prolymphocytic leukemia. Nat Med 3: 1155-1159
Stilgenbauer S, Winkler D, Ott G, Schaffner C, Leupolt E, Bentz M, Moller P, Muller-Hermelink HK, James MR, Lichter P, Dohner H (1999) Molecular characterization of $11 \mathrm{q}$ deletions points to a pathogenic role of the ATM gene in mantle cell lymphoma. Blood 94: 3262-3264

Stoppa-Lyonnet D, Soulier J, Lauge A, Dastot H, Garand R, Sigaux F, Stern M-H (1998) Inactivation of the ATM gene in T-cell prolymphocytic leukemias. Blood 91: 3920-3926

Su Y, Swift M (2000) Mortality rates among carriers of ataxia-telangiectasia mutant alleles. Ann Intern Med 133: 770-778

Swift M, Morrell D, Massey RB, Chase CL (1991) Incidence of cancer in 161 families affected by ataxia telangiectasia. $N$ Engl J Med 325: 1831-1836

Taylor AMR, Metcalfe JA, Thick J, Mak Y-F (1996) Leukemia and lymphoma in ataxia telangiectasia. Blood 87: 423-438

Thorstenson YR, Shen P, Tusher VG, Wayne TL, Davis RW, Chu G, Oefner PJ (2001) Global analysis of ATM polymorphism reveals significant functional constraint. Am J Hum Genet 69: 396-412

Tilly H, Bastard C, Delastre T, Duval CM, Bizet M, Lenormand B, Dauce J-P, Monconduit M, Piguet H (1991) Cytogenetic studies in untreated Hodgkin disease. Blood 77: 1298-1304

Vorechovsky I, Luo L, Dyer MJS, Catovsky D, Amlot PL, Yaxley JC, Foroni L, Hammarstrom L, Webster ADB, Yuille MAR (1997) Clustering of missense mutations in the ataxia-telangiectasia gene in a sporadic T-cell leukaemia. Nat Genet 17: $96-99$

Yuille MA, Coignet LJ, Abraham SM, Yaqub F, Luo L, Matutes E, BritoBabapulle V, Vorechovsky I, Dyer MJ, Catovsky D (1998) ATM is usually rearranged in T-cell prolymphocytic leukemias. Oncogene 16: 789-796 